\title{
NEW STRATEGY FOR DEVELOPMENT OF FUNCTIONAL PORK SAUSAGES WITH REDUCED NITRITES ADDITION
}

Desislava Vlahova-Vangelova*, Desislav Balev, Stefan Dragoev

Department of Meat and Fish Technology, Technological Faculty, University of Food Technologies, Plovdiv, Bulgaria

*Corresponding author: Dessislava Vlahova-Vangelova, E-mail address: desislava_vangelova@abv.bg

\section{ABSTRACT}

The aim of this study was to develop a new strategy for processing of functional cooked sausages with reduced nitrites addition manufactured using pork obtained from pigs fed with a supplement of 3.5 and $7.5 \mathrm{mg}$ dihydroquercetin (DHQ) (samples D1 and D2, respectively) or 0.255 and $0.545 \mathrm{~g}$ dry distilled rose petals (Rosa damascene) (DDRP) (samples R1 and R2, respectively)/kg live weight/d. The sensory properties, colour characteristics $\left(L^{*}, a^{*}, b^{*}\right)$, TBARS and shelf life of the sausages were studied. Lower concentration of used phytonutrients approve sensory acceptance of sausages with half added nitrites. Higher doses of DHQ and DDRP supplements increased the sausage $\mathrm{pH}$ by $3 \%(\mathrm{p}<0.05)$. The use of 0.545 g DDRP $/ \mathrm{kg}$ live weight/d as a feed supplement with subsequent sausage production decreased the $\mathrm{L}^{*}$ value and increased the redness $\left(\mathrm{a}^{*}\right)$ in sausages while the higher doses of DHQ show an opposite effect. Feed enrichment with DHQ or DDRP is appropriate for manufacturing functional sausages with half added nitrites due to the stabilizing effect on colour $\left(L^{*}, a^{*}, b^{*}\right)$ characteristics in dynamics, the decreasing of TBARS and the increasing of the sausages shelf life.

Keywords: dihydroquercetin, dry distilled rose petals, functional sausages, phytonutrient enrichment, pig's feed 
INTRODUCTION

In recent years the development of novel functional foods has been in the focus of the food industry. The increasing consumer health-care pays attention to using ingredients with preventive effect on a number of diseases in modern society with proven anticancer, antimutagenic, antioxidant and delaying degenerative effects (Kumar et al., 2015). The first approach to creating functional meat products is the addition of natural supplements with a healthy effect such as vegetables, proteins, antioxidants, probiotics and prebiotics, soybeans, fruits, lactic acid bacteria etc. during manufacturing (Todra and Reig, 2011). Many consumers preferred meat products without allergens formulated by eliminating of the ingredients causing different types of allergies (Arihara, 2006).

Using the second approach, the composition of meat products can also be improved by animal feed enrichment. Feed supplement with conjugated linoleic acid has an impact on the accumulation of fatty acids and the nutritional value of the meat (Terpstra et al., 2002). The feed enrichment with vitamin E inhibits the protein and lipid oxidation and improves the color stability (Cardinali et al., 2015). Linseed and rapeseed oil increased the long-chain PUFAs in meat (Lopez-Ferrer et al., 2001) and the addition of selenium is proven to have increased its muscular content by $66 \%$ (Jiang and Xiong, 2016). Algae also have been used to improve the nutritional value of feed (Christaki et al., 2010).

The use of herbs and spices like oregano (Origanum vulgare L.), rosemary (Rosmarinus officinalis L.) (Cardinali et al., 2015) as well as sage (Salvia officinalis L.) shows a high antioxidant capacity (Jiang and Xiong, 2016) and increases products shelf life.

Dihydroquercetin (DHQ) from Siberian larch (Larix sibirica Ledeb) is a powerful natural bioflavonoid antioxidant with proven antioxidative, capillary protective, hepatoprotective, 
radioprotective, anti-coagulant and anti-inflammatory properties. DHQ inhibits the oxidation of LDL-cholesterol in blood serum (Artem'eva et al., 2015).

An interesting by-product, a waste material in rose oil and rose water production, is the distilled rose petals. It is a typical Bulgarian raw material containing a wide range of antioxidant components - flavonoids with synergistic, antioxidative and antibacterial effect (Shikov et al., 2012). According to Balev et al. (2015) the broiler feed supplement with dry rose petals shows the improved feed conversion. In order to produce healthy meat products attempts have been made to reduce the nitrites during cooked sausages manufacturing (Vlahova-Vangelova et al., 2014).

The production of meat with functional properties by a modeled chemical composition and an increase in the nutritional value after feed supplementing (Nieto et al., 2010) is a chalenge and innovation. Information on the usage of enriched meat obtained after animal feed supplementing is not available. Therefore, the purpose of this study was to develop a new strategy for processing of functional cooked sausages with half added nitrites manufactured by using pork obtained from pigs fed with supplements of 3.5 and $7.5 \mathrm{mg}$ DHQ or 0.255 and $0.545 \mathrm{~g}$ DDRP/ $\mathrm{kg}$ live weight/ $\mathrm{d}$.

\section{MATERIALS AND METHODS}

\section{Feed supplements}

The dihydroquercetin powder from Siberian larch (Larix sibirica Ledeb) was provided by Flavitlife Bio JSCo (Sofia, Bulgaria). Distilled rose petals were supplied by Bulattars Production Company Ltd (Sofia, Bulgaria), Pavel Banya, Stara Zagora district. The byproduct after the rose oil distillation was pressed, dried and ground $(<0.4 \mathrm{~mm})$.

\section{Animal feeding, supplementation and harversting}


The pigs (Danube white breed) were bred on the State Enterprise Experimental Farm at Agricultural Institute; Shumen, Bulgaria divided into five groups (one control and four experimental) each comprised of 8 animals. The animals received a typical commercial diet libitum grower diet up to $60 \mathrm{~kg}$ live weight and a finisher up to $110 \mathrm{~kg}$. After 155 day at an average live weight of $72 \mathrm{~kg}$ the pigs diets were supplemented for the last 40 days as follows: control (C) commercial diet without any supplement; sample D1 - commercial diet with 3.5 $\mathrm{mg}$ DHQ/kg live weight/d supplement; sample D2 - commercial diet with $7.5 \mathrm{mg}$ DHQ/kg live weight/d supplement; sample R1 - commercial diet with $0.255 \mathrm{~g}$ DDRP/kg live weight/d supplement; sample R2 - commercial diet with or $0.545 \mathrm{~g}$ DDRP/kg live weight/d supplement.

After 40 days of supplemental feeding the pigs were transported and harvested at a processing plant (Unitemp Ltd., Voyvodinovo village, Plovdiv district, Bulgaria) in accordance with Council Regulations (EC) No 1/2005.

After $24 \mathrm{~h}$ chilling at $4^{\circ} \mathrm{C}$ each carcass was quartered between the $12-13$ rib, deboned and cold stored at $2 \pm 1^{\circ} \mathrm{C}$. The chilled (48 h) to $0 \pm 4^{\circ} \mathrm{C}$ pork rump (pH 6.40) and pork chest (pH 6.5) were used for sausage production.

\section{Sausage manufacturing}

The sausages were produced in accordance with the requirements of the cooked meat product appropriate for EU (Table 1). Pork rump and pork chest obtained from five animal groups (C, D1, D2, R1, R2) were separately cut into pieces and used for the production of six sausage samples. Each filling mass was manufactured by mixing with salt and phosphates and blended in a cutter with an addition of flake ice. The nitrites in sausages from experimental groups D1, D2, R1, R2 were added in half. Pork rumps and pork chests from control group (C) were used for the production of two sausage control samples: control C - with $100 \%$ nitrite addition 
and control sample $\mathrm{C}^{1 / 2}$ - with half-added nitrites (Table 1). After filling in moisture and gases no-permeable five-layer polymer casings the sausages were cooked to an internal temperature of $72^{\circ} \mathrm{C}$ and chilled in cold water. The examinations were made dynamically on 1 and 7 day of the sausage refrigerated storage at $0- \pm 4^{\circ} \mathrm{C}$.

The sodium chloride (salt), sugar and sodium nitrite (E250) were provided from the local market.

Table 1. Formulation of different samples functional cooked sausages

\begin{tabular}{lcccccc}
\hline & C & C1/2 & D1 & D2 & R1 & R2 \\
\hline $\begin{array}{l}\text { Feed } \\
\text { supplementation }\end{array}$ & $\begin{array}{c}\text { No } \\
\text { suppl. }\end{array}$ & $\begin{array}{c}\text { No } \\
\text { suppl. }\end{array}$ & $\begin{array}{c}3.5 \mathrm{mg} \text { DHQ/ } \\
\mathrm{kg} \text { live weight/ } \mathrm{d}\end{array}$ & $\begin{array}{c}\text { 7.5 } \mathrm{kg} \text { DHQ/ } / \\
\mathrm{kg} \text { live weight/ }\end{array}$ & $\begin{array}{c}0.255 \mathrm{~g} \text { DDRP/ } \\
\mathrm{kg} \text { live weight/ d }\end{array}$ & $\begin{array}{c}\text { 0.545 g DDRP live weight/ } \\
\text { Sausage ingradients }\end{array}$ \\
\hline Pork rump, g/kg & 500 & 500 & 500 & 500 & 500 & 500 \\
Pork chest, g/kg & 500 & 500 & 500 & 500 & 200 & 200 \\
Flake ice, g/kg & 200 & 200 & 200 & 200 & 200 & 200 \\
Sodium chloride, g/kg & 20 & 20 & 20 & 20 & 20 & 20 \\
Polyphosphates, g/kg & 2 & 2 & 2 & 2 & 2 & 2 \\
Sodium nitrite, g/kg & 0.10 & 0.05 & 0.05 & 0.05 & 0.05 & 0.05 \\
\hline
\end{tabular}

\section{Sensory analysis}

The sensory properties (cross sectional view, flavor, taste, color, texture) of the sausages were determined with a panel consisting of five members with proven tasting abilities (Meilgaard et al., 1999). The samples were scored using 1 to 5 scales.

\section{Colour characteristics}

The color properties CIE L*, $\mathrm{a}^{*}, \mathrm{~b}^{*}$ (Hunt et al., 2012) of the sausages on $1^{\text {st }}$ day of storage at $0 \pm 4^{\circ} \mathrm{C}$ were determined with Colorimeter Konica Minolta model CR-410 (Konica Minolta Holding, Inc., Ewing, New Jersey, USA), purchased by Sending, Inc. (Tokyo, Japan). The changes of the color properties in the dynamics of the sausage surface cross-sectional views during the $60 \mathrm{~min}$ air exposure were examined on the $1^{\text {st }}$ day of storage. 


\section{pH value}

The $\mathrm{pH}$ value of the samples was determined by $\mathrm{pH}$-meter MS 2004, $\mathrm{pH}$ combination recorder S 450 CD (Sensorex pH Electrode Station, USA) (Young et al., 2004).

\section{2-Thiobarbituric acid reactive substances (TBARS)}

The double beam UV-VIS spectrophotometer Camspec model M550 (Camspec Ltd, Cambridge, UK) was used for determination of the secondary products of the lipid oxidation expressed by malondialdehyde content (Botsoglou et al., 1994).

\section{Microbiological assay}

The samples for the microbiological assay were prepared by tenfold logarithmic dilution after homogenization with $90 \mathrm{~mL}$ of $0.85 \%$ sodium chloride for 2 min at $200 \mathrm{~min}^{-1}$ (Merck Bulgaria Joint-stock company, Sofia, Bulgaria) in stomacher bags (Seward Ltd, Worthing, West Sussex, UK). Once diluted, $1 \mathrm{~cm}^{3}$ of the sample was added to sterile Petri plates (in triplicate for each dilution) with cooled to $45^{\circ} \mathrm{C}$ suitable agar (Sharma et al., 2005). The total viable count (TVC) was determined after $72 \mathrm{~h}$ incubation at $28^{\circ} \mathrm{C}$ on a plate count agar (PCA, Merck Bulgaria Joint-stock company, Sofia, Bulgaria) following the ISO 4833:2003 procedure and the count of yeast - after incubation of the same type on potato-dextrose agar Merck 1.10130 (Merck Bulgaria Joint-stock company, Sofia, Bulgaria) (Gelabert et al., 2003).

\section{Statistical analysis}

Statistical analysis of the average values of five time reps was made. All statistical procedures for the data of different samples were analyzed by SAS software (SAS Institute, Inc. 1990). The Student-Newman-Keuls multiple range test was used to compare differences among means. The results were expressed as mean values and standard errors of the mean. A p-value less than $0.05(\mathrm{p}<0.05)$ was considered as significant. 


\section{RESULTS AND DISSCUSON}

\section{pH value}

$\mathrm{pH}$ in control sample $\mathrm{C}$ (Table 2 ), half added nitrites $\left(\mathrm{C}^{1 / 2}\right.$.), as well as samples $\mathrm{D} 1$ does not differ significantly $(\mathrm{p}>0.05)$. On the contrary, sausages from samples D2 and R2 had 3\% higher $\mathrm{pH}(\mathrm{p}<0.05)$. For both used feed antioxidants the higher daily dose $(7.5 \mathrm{mg} \mathrm{DHQ} / \mathrm{kg}$ live weight/d or $0.545 \mathrm{~g} / \mathrm{kg}$ DDRP/live weight/d increased the $\mathrm{pH}$ in sausages with half added nitrites. The results confirmed previous research that the feed supplements not only change the meat $\mathrm{pH}$ (Wiklund et al., 2001) but also influence the $\mathrm{pH}$ of the manufactured sausages (Table 2).

Table 2. Changes in $\mathrm{pH}$, colour $\left(\mathrm{L}^{*}, \mathrm{a}^{*}, \mathrm{~b}^{*}\right)$ characteristics, TBARS and microflora of studied sausage samples

\section{Samples}

\begin{tabular}{|c|c|c|c|c|c|c|c|}
\hline & $\begin{array}{l}\text { Day of } \\
\text { storage }\end{array}$ & C & $\mathrm{C}^{1 / 2}$ & D1 & D2 & R1 & $\mathbf{R} 2$ \\
\hline$\overline{\mathrm{pH}}$ & 1 & $6,50^{\mathrm{a}} \pm 0,05$ & $6,50^{a} \pm 0,05$ & $6,50^{\mathrm{a}} \pm 0,05$ & $6,70^{b} \pm 0,05$ & $6,60^{\mathrm{a}, \mathrm{b}} \pm 0,05$ & $6,70^{b} \pm 0,05$ \\
\hline $\mathrm{L}^{*}$ & 1 & $59,57^{\mathrm{a}} \pm 0,04$ & $58,97^{\mathrm{b}} \pm 0,06$ & $59,19^{\mathrm{c}} \pm 0,03$ & $61,12^{\mathrm{e}} \pm 0,04$ & $60,74^{\mathrm{d}} \pm 0,12$ & $58,43^{\mathrm{a}} \pm 0,12$ \\
\hline$a^{*}$ & 1 & $11,76^{\mathrm{b}} \pm 0,03$ & $12,70^{\mathrm{d}} \pm 0,59$ & $12,39^{\mathrm{c}} \pm 0,04$ & $11,22^{\mathrm{a}} \pm 0,01$ & $11,25^{\mathrm{a}} \pm 0,06$ & $12,80^{\mathrm{d}} \pm 0,02$ \\
\hline $\mathrm{b}^{*}$ & 1 & $6,72^{\mathrm{d}} \pm 0,06$ & $5,32^{\mathrm{a}} \pm 0,05$ & $5,77^{\mathrm{b}} \pm 0,04$ & $6,98^{\mathrm{e}} \pm 0,01$ & $6,17^{\mathrm{c}} \pm 0,02$ & $6,18^{c} \pm 0,12$ \\
\hline $\begin{array}{l}\text { TBARS, } \\
\text { mgMDA/kg }\end{array}$ & 1 & $0,41^{\mathrm{a}} \pm 0,02$ & $0,53^{\mathrm{b}} \pm 0,03$ & $0,58^{\mathrm{b}} \pm 0,02$ & $0,54^{\mathrm{b}} \pm 0,04$ & $0,46^{\mathrm{a}} \pm 0,03$ & $0,42^{\mathrm{a}} \pm 0,04$ \\
\hline $\begin{array}{l}\text { TBARS, } \\
\text { mgMDA/kg }\end{array}$ & 7 & $0,43^{\mathrm{a}} \pm 0,04$ & $0,75^{\mathrm{c}} \pm 0,07$ & $0,67^{c} \pm 0,05$ & $0,56^{\mathrm{b}} \pm 0,04$ & $0,51^{\mathrm{a}, \mathrm{b}} \pm 0,06$ & $0,68^{\mathrm{c}} \pm 0,09$ \\
\hline $\begin{array}{l}\text { TVC, } \\
\log \mathrm{cfu} / \mathrm{g}\end{array}$ & 7 & $4,00^{\mathrm{a}} \pm 0,20$ & $4,70^{\mathrm{b}} \pm 0,10$ & $4,30^{\mathrm{a} a} \pm 0,15$ & $4,30^{\mathrm{a}} \pm 0,20$ & $4,00^{\mathrm{a}} \pm 0,12$ & $4,30^{\mathrm{a}} \pm 0,10$ \\
\hline $\begin{array}{l}\text { Yeasts and } \\
\text { molds, } \\
\log \text { cfu/g }\end{array}$ & 7 & $4,00^{\mathrm{a}} \pm 0,25$ & $5,00^{\mathrm{b}} \pm 0,20$ & $4,54^{\mathrm{a}} \pm 0,30$ & $4,81^{\mathrm{a}, \mathrm{b}} \pm 0,15$ & $4,54^{\mathrm{a}} \pm 0,30$ & $4,70^{\mathrm{a}, \mathrm{b}} \pm 0,10$ \\
\hline
\end{tabular}

\section{Sensory evaluation}

The highest scores for cross sectional view and color were identified in samples $\mathrm{C}, \mathrm{C}^{1} / 2$ and

157 the sausages from sample D1. The sensory panel confirmed the best flavor and taste in sausages from sample D1 followed by those from sample R1 and sample C1/2 (Fig. 1). 
The lowest flavor scores were obtained for sausages from samples D2 and R2. As many researchers who have explored the effect of feed enriching on meat quality (Jerónimo et al., 2009; Sobolev et al., 2017) we can confirm that the concentration of the feed supplements is a very important factor for the sensory quality of pork functional sausages. It is clear that lower doses of DHQ in sample D1 and DDRP in sample R2 are appropriate for a sensory acceptance of the produced sausages with half added nitrites (Fig. 1).

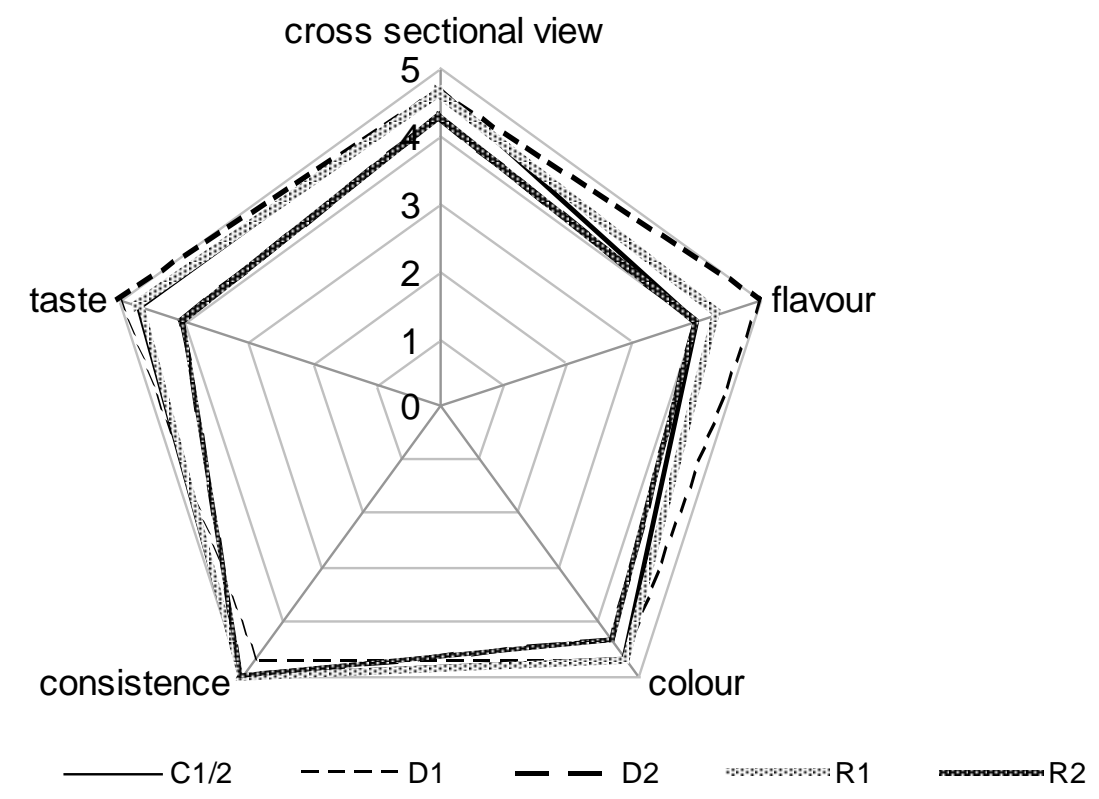

Figure 1. Sensory properties of studied sausages

\section{Colour characteristics $\left(\mathrm{L}^{*}, \mathbf{a}^{*}, \mathbf{b}^{*}\right)$}

On the first day of storage $\left(0 \pm 4^{\circ} \mathrm{C}\right)$ the highest color lightness $\mathrm{L} *$ (Table 2$)$ was established in sausages from sample D2 $(\mathrm{p}<0.05)$. On the contrary, the lowest $\mathrm{L} *$ value $(\mathrm{p}<0.05)$ was found in sausages from sample R2. Closest to the control sample with $100 \%$ nitrites $\mathrm{C}$ was the colour lightness in sausages from sample D1 while cut surface $\mathrm{L}^{*}$ value in sample D2 was $2.3 \%$ higher $(\mathrm{p}<0.05)$. Both the type and the concentration of supplements (DHQ or DDRP) in pigs' feeding affect the colour lightness L *. Higher doses of DDRP supplement reduced the $\mathrm{L}^{*}$ value in sausages from sample $\mathrm{R} 2$ while in sample D2 the $\mathrm{L}^{*}$ value increased by $2.3 \%$ 
( $p$ < 0.05) compared to C. Vlahova-Vangelova et al., (2014) established that rose petal extract added during processing of sausage with half added nitrits reduces the $\mathrm{L}^{*}$ component of the cut surface compared to the $100 \%$ nitrite control sample (Table 2).

Both the use of DDRP as feed supplement with subsequent sausage manufacturing and DDRP addition during sausage processing decreased the colour lightness $\mathrm{L}^{*}$ in the produced sausages with half added nitrites(Table 2).

Compared to the sample C (Table 2) sausages with a higher dose of DHQ enriched meat (sample D2) as well as a lower supplement of DDRP (sample R1) had lower colour redness a $*(p<0.05)$. On the contrary, in sausages from samples D1 and R2 the $a^{*}$ value was higher. Comparing the six studied samples $(\mathrm{C}, \mathrm{C} 1 / 2, \mathrm{D} 1, \mathrm{D} 2, \mathrm{R} 1, \mathrm{R} 2)$ the closest a* values to conrols C (with 100\% nitrites addition) were found in samples D2 and R1 (Table 2). The conclusion was made that two used phytonutrients had different impact on the colour redness $a^{*}$. The increase of DHQ supplement decreased the $a^{*}$ value while the samples from meat enriched with higher concentration of DDRP (R2) significantly increased redness (8.84\%) in pork cooked sausages.

On the first day of storage $\left(0 \pm 4^{\circ} \mathrm{C}\right)$ the lowest $\mathrm{b}^{*}$ value (of colour yellowness) was found on the cut surface of the sausages from sample $\mathrm{C}^{1} \frac{1}{2}$ followed by samples $\mathrm{D} 1, \mathrm{R} 1$ and $\mathrm{R} 2$. Compared to control sample C (with 100\% nitrites addition) the established decrease ( $\mathrm{p}<$ 0.05 ) was $26 \%, 16.5 \%, 8.7 \%$ and $8.7 \%$ respectively (Table 2 ). A decrease in the $\mathrm{b} *$ value after addition of rose petal extract during the sausages processing had been found previously by Vlahova-Vangelova et al. (2014) too. In sausages from samples D2 and R1 with half added nitrites yellow color component $\mathrm{b} *$ was found to be closest to sample $\mathrm{C}$. 


\section{TBARS}

On the first day of the sausage storage $\left(0 \pm 4^{\circ} \mathrm{C}\right)$ the lowest TBARS (Table 2) was found in the controls $\mathrm{C}$ followed by sausages from DDRP enriched meat with half added nitrites (samples R1 and R2) ( $p>0.05)$.

In comparison to sample $\mathrm{C}$ after 7 days of storage $\left(0 \pm 4^{\circ} \mathrm{C}\right)$ controls $\mathrm{C}^{1 / 2}$ had two times higher content of TBARS ( $\mathrm{p}<0.05)$. In $\mathrm{C}$ sausages from sample C1/2 TBARS increased by $41 \%$ for a 7- day storage period $\left(0 \pm 4^{\circ} \mathrm{C}\right)$. The significant oxidative stability in lipid fraction was found in control $\mathrm{C}$ as well as in D2 and R1 sausages (Table 2). For the mentioned two samples TBARS does not change significantly $(\mathrm{p}>0.05)$ for the seven-day storage period $\left(0 \pm 4^{\circ} \mathrm{C}\right)$.

Similar to our results were reported for oregano, rosemary, vitamin E (Cardinali et al., 2015), tocopherol (Ventanas et al., 2007) and natural phenolic antioxidants (Jiang and Xiong, 2016). We can conclude that feed supplement with DHQ and DDRP rich in phenolic compounds decreases the formation of secondary products of lipid oxidation and can be used successfully for manufacturing of functional meat products with half added nitrites.

\section{Microbiological analysis}

The reduction of nitrites by $50 \%$ in sample $\mathrm{C}^{1 / 2}$ was not effective for the microbial growth suppressing (Table 2). The total viable count in sample $\mathrm{C}^{1} \frac{1}{2}$ was $17.5 \%$ higher than in controls C (100\% nitrite addition). No significant difference in the total viable count was established between controls $\mathrm{C}$ and sausages from other four samples D1 and D2or R1 and R2. In comparison to sample $\mathrm{C}^{1} \frac{1}{2}$ yeast and mold growth was suppressed in samples D1 and R1 too. Our results are in accordance with the results presented by Khan et al. (2011) about the beneficial effect of bioactive compounds and probiotics added as feed supplement or in filling mass on the shelf life of functional sausages. Many herbs and spices like black pepper, clove, oregano, thyme, (Dalle Zotte, 2016) cinnamon, onion, and garlic (Kreig, 2013) inhibit the 
microbial growth due to their essential oils content. The strong antimicrobial activity of rosemary was established due to the high level of phenolic antioxidants (Cardinali et al., 2015). DHQ and DDRP as phytonutrients rich in phenolic compounds have strong antioxidant activity too (Shikov et al., 2012; Artem'eva et al., 2015).

The enrichment of the pigs' feed with dihydroquercetin (3.5 or $7.5 \mathrm{~g} / \mathrm{kg}$ live weight/d) or dry distilled rose petals $(0.252$ or $0.545 \mathrm{~g} / \mathrm{kg}$ live weight $/ \mathrm{d})$ inhibits the microbial growth in the sausages from samples D1, D2, R1 and R2 during their seven-day period of refrigerated storage $\left(0- \pm 4^{\circ} \mathrm{C}\right)$. The lower concentrations of phytonutrients as feed supplement $(3.5 \mathrm{mg} / \mathrm{kg}$ DHQ or $0.252 \mathrm{~g} / \mathrm{kg}$ DDRP live weight/d) had better impact for yeasts and moulds growth inchibition (Table 2).

\section{Dynamics of the colour characteristics during 60 min exposure under air conditions}

After 60 min of air exposure the most stable color lightness $\mathrm{L}^{*}$ was found in two controls $\mathrm{C}$ and $\mathrm{C}^{1} \frac{2}{2}$ followed by samples $\mathrm{D} 2$ and $\mathrm{R} 1$ (Table 3 ). For the mentioned four samples $\left(\mathrm{C}, \mathrm{C} 1 \frac{1}{2}\right.$, $\mathrm{D} 2, \mathrm{R} 1)$ the first $\mathrm{L}^{*}$ value $(0 \mathrm{~min})$ and the last $\mathrm{L}^{*}$ value $(60 \mathrm{~min})$ do not differ significantly ( $\mathrm{p}$ $>0.05)$.

The other two samples D1 and R2 show different trends. In sausages from sample R2 the color lightness $L^{*}$ significantly decreased by $33.7 \%(p<0.05)$ for 60 min while in sample D1 $L^{*}$ value slightly increased. The sausages from sample D1 are the only samples with color lightness increasing after a 60 minute of air exposure (Table 3).

The cut surface redness a* traced after 60 min of air exposure decreased in all tested sausages but most significantly with $37.90 \%$ ( $\mathrm{p}<0.05$ ) was the decrease in sample $\mathrm{C}^{1 / 2}$ (Table 2). More stable was the $a^{*}$ value after 60 min of air exposure in samples D2, R1 and R2 with a decrease of $32.30 \%, 33.7 \%$ and $33.75 \%(p<0.05)$ respectively. Similar changes were found in the colour yellowness $b^{*}$ studied in dynamics. Once again the most significant decrease was 
established after 60 min of air exposure in the controls with half added nitrites - $\mathrm{C}^{1 / 2}$. The supplement with DHQ and DDRP in pigs' diet stabilized the $a^{*}$ and $b^{*}$ values of the manufactured sausages with half added nitrites. Our results show that after a feed enrichment with DHQ or DDRP the meat is suitable for processing the sausages with half nitrites addition and ensures stable colour ( $\left.\mathrm{L}^{*}, \mathrm{a}^{*}, \mathrm{~b}^{*}\right)$ characteristics (Table 3 ).

Table 3. Chenges of colour lightness $\left(\mathrm{L}^{*}\right)$, redness $\left(\mathrm{a}^{*}\right)$ and yellowness $\left(\mathrm{b}^{*}\right)$ in dynamics during the 60 minutes air exposure of sausages cut surface sectional views

\begin{tabular}{|c|c|c|c|c|c|c|c|}
\hline \multicolumn{8}{|c|}{ L*value } \\
\hline $\begin{array}{l}\text { Time, } \\
\text { min }\end{array}$ & $\mathbf{0}$ & 10 & 20 & 30 & 40 & 50 & 60 \\
\hline $\mathbf{C}$ & $59,57^{\mathrm{c}, \mathrm{v}} \pm 0,04$ & $59,28^{\mathrm{b}, \mathrm{w}} 0,05$ & $59,31^{\mathrm{b}, \mathrm{y}} \pm 0,09$ & $59,30^{\mathrm{b}, \mathrm{y}} \pm 0,04$ & $59,30^{\mathrm{b}, \mathrm{x}} \pm 0,035$ & $59,28^{\mathrm{b}, \mathrm{x}} \pm 0,04$ & $59,16^{\mathrm{a}, \mathrm{x}} \pm 0,03$ \\
\hline $\mathrm{C}^{1} / 2$ & $58,97^{\mathrm{c}, \mathrm{w}} \pm 0,06$ & $58,96^{\mathrm{c}, \mathrm{y}} \pm 0,01$ & $58,96^{\mathrm{c}, \mathrm{x}} \pm 0,01$ & $58,94^{\mathrm{c}, \mathrm{x}} \pm 0,05$ & $58,74^{\mathrm{b}, \mathrm{v}} \pm 0,055$ & $58,72^{\mathrm{b}, \mathrm{w}} 0,03$ & $58,52^{\mathrm{a}, \mathrm{v}} \pm 0,07$ \\
\hline D1 & $59,19^{\mathrm{c}, \mathrm{x}} 0,03$ & $59,34^{\mathrm{c}, \mathrm{x}} \pm 0,30$ & $59,00^{\mathrm{b}, \mathrm{x}} \pm 0,07$ & $58,94^{\mathrm{b}, \mathrm{a}, \mathrm{x}} \pm 0,17$ & $58,90^{\mathrm{b}, \mathrm{w}} 0,04$ & $58,75^{\mathrm{a}, \mathrm{w}} \pm 0,05$ & $58,78^{\mathrm{a}, \mathrm{w}} \pm 0,08$ \\
\hline D2 & $61,12^{\mathrm{a}, \mathrm{z}} \pm 0,04$ & $61,62^{\mathrm{d}, \mathrm{z}} \pm 0,04$ & $61,62^{\mathrm{d}, \mathrm{z}} \pm 0,04$ & $60,77^{\mathrm{a}, \mathrm{z}} \pm 0,61$ & $61,46^{\mathrm{c}, \mathrm{z}} \pm 0,04$ & $61,45^{\mathrm{c}, \mathrm{z}} \pm 0,06$ & $61,30^{\mathrm{b}, \mathrm{y}} \pm 0,03$ \\
\hline R1 & $60,74^{\mathrm{a}, \mathrm{y}} 0,12$ & $61,05^{\mathrm{b}, \mathrm{z}} \pm 0,16$ & $61,05^{\mathrm{b}, \mathrm{z}} \pm 0,06$ & $61,28^{\mathrm{c}, \mathrm{z}} \pm 0,09$ & $60,80^{\mathrm{a}, \mathrm{y}} \pm 0,03$ & $60,73^{\mathrm{a}, \mathrm{y}} \pm 0,06$ & $60,79^{\mathrm{a}, \mathrm{z}} \pm 0,08$ \\
\hline $\mathbf{R 2}$ & $58,43^{\mathrm{b}, \mathrm{c}, \mathrm{v}} 0,12$ & $58,48^{\mathrm{d}, \mathrm{v}} \pm 0,01$ & $58,48^{\mathrm{a}, \mathrm{w}} \pm 0,02$ & $58,46^{\mathrm{a}, \mathrm{w}} \pm 0,02$ & $58,27^{\mathrm{b}, \mathrm{u}} \pm 0,08 \quad 5$ & $58,37^{\mathrm{c}, \mathrm{v}} \pm 0,03$ & $58,13^{\mathrm{a}, \mathrm{u}} \pm 0,02$ \\
\hline \multicolumn{8}{|c|}{$a^{*}$ value } \\
\hline $\mathbf{C}$ & $11,76^{\mathrm{g}, \mathrm{x}} \pm 0,03$ & $10,91^{\mathrm{f}, \mathrm{w}} \pm 0,02$ & $10,27^{\mathrm{e}, \mathrm{x}} \pm 0,02$ & $29,76^{\mathrm{d}, \mathrm{x}} \pm 0,03$ & $9,39^{\mathrm{c}, \mathrm{x}} \pm 0,02$ & $9,08^{\mathrm{b}, \mathrm{x}} \pm 0,02$ & $8,86^{\mathrm{a}, \mathrm{x}} \pm 0,01$ \\
\hline $\mathrm{C}^{1} / 2$ & $12,70^{\mathrm{g}, \mathrm{z}} \pm 0,59$ & $11,27^{\mathrm{f}, \mathrm{x}} \pm 0,01$ & $10,60^{\mathrm{e}, \mathrm{x}} \pm 0,02$ & $210,05^{\mathrm{d}, \mathrm{x}} \pm 0,03$ & $7,93^{\mathrm{a}, \mathrm{x}} \pm 0,02$ & $9,43^{c, x} \pm 0,01$ & $9,21^{\mathrm{b}, \mathrm{x}} \pm 0,01$ \\
\hline D1 & $12,39^{\mathrm{g}, \mathrm{y}} \pm 0,04$ & $11,55^{\mathrm{f}, \mathrm{y}} \pm 0,07$ & $10,77^{\mathrm{e}, \mathrm{x}} \pm 0,03$ & $310,19^{\mathrm{d}, \mathrm{x}} \pm 0,05$ & $9,71^{\mathrm{c}, \mathrm{x}} \pm 0,01$ & $9,39^{\mathrm{b}, \mathrm{x}} \pm 0,04$ & $9,18^{\mathrm{a}, \mathrm{x}} \pm 0,02$ \\
\hline D2 & $11,22^{\mathrm{f}, \mathrm{w}} \pm 0,01$ & $10,41^{\mathrm{e}, \mathrm{u}} \pm 0,01$ & $9,72^{\mathrm{d}, \mathrm{x}} \pm 0,02$ & $9,90^{\mathrm{d}, \mathrm{x}} \pm 0,58$ & $8,85^{\mathrm{c}, \mathrm{x}} \pm 0,02$ & $8,58^{\mathrm{b}, \mathrm{x}} \pm 0,02$ & $8,48^{\mathrm{a}, \mathrm{x}} \pm 0,01$ \\
\hline R1 & $11,25^{\mathrm{g}, \mathrm{w}} \pm 0,06$ & $10,50^{\mathrm{f}, \mathrm{v}} \pm 0,05$ & $9,76^{\mathrm{e}, \mathrm{x}} \pm 0,01$ & $9,22^{\mathrm{d}, \mathrm{x}} \pm 0,01$ & $8,82^{\mathrm{c}, \mathrm{x}} \pm 0,01$ & $8,58^{\mathrm{b}, \mathrm{x}} \pm 0,03$ & $8,41^{\mathrm{a}, \mathrm{x}} \pm 0,01$ \\
\hline $\mathbf{R 2}$ & $12,80^{\mathrm{g}, \mathrm{z}} \pm 0,02$ & $11,87^{\mathrm{f}, \mathrm{z}} \pm 0,05$ & $11,08^{\mathrm{e}, \mathrm{x}} \pm 0,05$ & $5 \quad 10,48^{\mathrm{d}, \mathrm{x}} \pm 0,01$ & $10,07^{\mathrm{c}, \mathrm{x}} \pm 0,02$ & $9,78^{\mathrm{b}, \mathrm{x}} \pm 0,03$ & $9,57^{\mathrm{a}, \mathrm{x}} \pm 0,01$ \\
\hline \multicolumn{8}{|c|}{$b^{*}$ value } \\
\hline $\mathbf{C}$ & $6,72^{\mathrm{a}, \mathrm{y}} \pm 0,06$ & $7,52^{\mathrm{b}, \mathrm{y}} \pm 0,02$ & $7,73^{\mathrm{c}, \mathrm{y}} \pm 0,02$ & $8,14^{\mathrm{d}, \mathrm{z}} \pm 0,02$ & $8,30^{\mathrm{e}, \mathrm{y}} \pm 0,01$ & $8,49^{\mathrm{f}, \mathrm{y}} \pm 0,03$ & $8,66^{\mathrm{g}, \mathrm{x}} \pm 0,01$ \\
\hline $\mathrm{C}^{1} / 2$ & $5,32^{\mathrm{a}, \mathrm{v}} \pm 0,05$ & $7,18^{\mathrm{b}, \mathrm{x}} \pm 0,01$ & $7,51^{\mathrm{c}, \mathrm{v}} \pm 0,01$ & $7,81^{\mathrm{d}, \mathrm{y}} \pm 0,01$ & $8,03^{\mathrm{e}, \mathrm{v}} \pm 0,01$ & $8,19^{\mathrm{f}, \mathrm{v}} \pm 0,01$ & $8,34^{\mathrm{g}, \mathrm{w}} \pm 0,02$ \\
\hline D1 & $5,77^{\mathrm{a}, \mathrm{w}} \pm 0,04$ & $6,77^{\mathrm{b}, \mathrm{v}} \pm 0,01$ & $7,15^{\mathrm{c}, \mathrm{u}} \pm 0,05$ & $7,43^{\mathrm{d}, \mathrm{x}} \pm 0,02$ & $7,65^{\mathrm{e}, \mathrm{u}} \pm 0,02$ & $7,84^{\mathrm{f}, \mathrm{u}} \pm 0,01$ & $7,96^{\mathrm{g}, \mathrm{v}} \pm 0,02$ \\
\hline D2 & $6,98^{\mathrm{a}, \mathrm{z}} \pm 0,01$ & $7,64^{\mathrm{b}, \mathrm{z}} \pm 0,01$ & $8,04^{\mathrm{c}, \mathrm{z}} \pm 0,01$ & $8,03^{\mathrm{c}, \mathrm{y}, \mathrm{z}} \pm 0,52$ & $8,56^{\mathrm{c}, \mathrm{z}} \pm 0,02$ & $8,79^{\mathrm{d}, \mathrm{z}} \pm 0,03$ & $8,90^{\mathrm{d}, \mathrm{z}} \pm 0,02$ \\
\hline R1 & $6,17^{\mathrm{a}, \mathrm{x}} \pm 0,02$ & $7,06^{\mathrm{b}, \mathrm{w}} \pm 0,01$ & $7,55^{\mathrm{c}, \mathrm{w}} \pm 0,01$ & $7,99^{\mathrm{d}, \mathrm{y}, \mathrm{z}} \pm 0,29$ & $8,07^{\mathrm{d}, \mathrm{w}} \pm 0,02$ & $8,24^{\mathrm{e}, \mathrm{w}} \pm 0,03$ & $8,35^{\mathrm{f}, \mathrm{w}} \pm 0,02$ \\
\hline $\mathbf{R 2}$ & $6,18^{\mathrm{a}, \mathrm{x}} \pm 0,12$ & $7,09^{\mathrm{b}, \mathrm{w}} \pm 0,02$ & $7,61^{\mathrm{c}, \mathrm{x}} \pm 0,02$ & $7,95^{\mathrm{d}, \mathrm{y}} \pm 0,01$ & $8,21^{\mathrm{e}, \mathrm{x}} \pm 0,03$ & $8,42^{\mathrm{f}, \mathrm{x}} \pm 0,02$ & $8,58^{\mathrm{g}, \mathrm{y}} \pm 0,01$ \\
\hline
\end{tabular}

a, b, c Means in the same row with different superscript letters differ significantly $(\mathrm{P}<0.05)$.

SEM- standard error of the mean.

\section{CONCLUSIONS}

The results obtained allow us to conclude that using a new strategy for processing of functional cooked sausages with a half added nitrites was developed. For this purpose there was applied a new approach to using pork obtained from pigs' feed with supplements with $3.5 \mathrm{mg}$ or $7.5 \mathrm{mg}$ dihydroquercetin and $0.255 \mathrm{~g}$ or $0.545 \mathrm{~g}$ dry distilled rose petals (Rosa 
damascene Mill.)/kg live weight/d. There is evidence that pork obtained from pigs' feed with supplements of 7.5 DHQ mg or $0.545 \mathrm{~g}$ DDRP/ $\mathrm{kg}$ live weight $/ \mathrm{d}$ increased the $\mathrm{pH}$ of the manufactured sausages. The addition of $3.5 \mathrm{DHQ}$ or $0.252 \mathrm{DDRP} / \mathrm{kg}$ live weight/d are appropriate for a better sensory acceptance of the produced sausages with half nitrites addition. Pigs' feed enrichment with DHQ or DDRP decreased the formation of secondary products of lipid oxidation and increased the shelf life of the cooked sausages with half added nitrites.

\section{Conflict of interest}

The authors confirm that there are no known conflicts of interest associated with this publication.

\section{Funding sources}

The project was supported by National Research Program "Young Scientists and Postdocs".

\section{RFFERENCES}

1. Arihara K., 2006. Strategies for designing novel functional meat products. Meat Science. 74(1): 219-229.

2. Artem'eva, O. A., Pereselkova, D.A., Fomichev, Yu.P. 2015. Dihydroquercetin, the bioactive substance, to be used against pathogenic mickroorganisms as an alternative to antibiotics. Agricultural Biology. 50(4): 513-519.

3. Balev, D., Vlahova-Vangelova, D., Mihalev, K., Shikov, V., Dragoev, S., Nikolov, V. 2015. Application of natural dietary antioxidants in broiler feeds. Journal of Mountain Agriculture on the Balkans. 18(2): 224-232.

4. Botsoglou, N.A., Fletouris, D.J., Papageorgiou, G.E., Vassilopoulos, V.N., Mantis, 
A.J., Trakatellis, A.G. 1994. Rapid, sensitive, and specific thiobarbituric acid method for measuring lipid peroxidation in animal tissue, food, and feedstuff samples. Journal of Agriculture and Food Chemistry. 42(9): 1931-1937.

5. Cardinali, R., Cullere, M., Dal Bosco, A., Mugnai, C., Ruggeri, S., Mattioli, S., Castellini, C., Trabalza Marinucci, M., Dalle Zotte, A. 2015. Oregano, rosemary and Vitamin E dietary supplementation in growing rabbits: effect on growth performance, carcass traits, bone development and meat chemical composition. Livestock Science. 175(5): 83-89.

6. Christaki, E., Karatzia, M., Florou-Paneri, P. 2010. The use of algae in animal nutrition. Journal of Hellenic Veterinary Medical Society. 61(3): 267-276.

7. Council Regulation (EC) No 1/2005 of 22 December 2004 on the protection of animals during transport and related operations and amending Directives 64/432/EEC and 93/119/EC and Regulation (EC) No 1255/97. Official Journal, L 3, 5.1.2005, pp. 1-44.

8. Dalle Zotte, A., Celia, C., Szendrö, Z. 2016. Herbs and spices inclusion as feedstuff or additive in growing rabbit diets and as additive in rabbit meat: A review. Livestock Science. 189(7): 82-90.

9. Gelabert, J., Gou, P., Guerrero, L., Arnau, J. 2003. Effect of sodium chloride replacement on some characteristics of fermented sausages. Meat Science. 65(2): 833-839.

10. Hunt, M.C., King, A. 2012. AMSA Meat Color Measurement Guidelines (pp. 1135). American Meat Science Association, Champaign, Illinois, USA.

11. ISO 4833:2003. Microbiology of food and animal feeding stuffs. Horizontal method for the enumeration of microorganisms-colony-count technique at $30^{\circ} \mathrm{C}$.

12. Jerónimo, E., Alves, S. P., Prates, J.A., Santos-Silva, J., Bessa, R. J. 2009. Effect of dietary replacement of sunflower oil with linseed oil on intramuscular fatty acids of lamb meat. Meat Science. 83(3): 499-505.

13. Jiang, J. and Xiong, Y. L. 2016. Natural antioxidants as food and feed additives to 
promote health benefits and quality of meat products: A review. Meat Science. 120(10): 107117.

14. Khan, M.I., Arshad, M.S., Anjum, F.M., Sameen, A., Gill, W.T. 2011. Meat as a functional food with special reference to probiotic sausages. Food Research International. 44(10): 3125-3133.

15. Krieg, R. 2013. Herbs and spices for improving the gastrointestinal health of the rabbit. In: Proceedings of the $25^{\text {th }}$ Hungarian Conference on Rabbit Production (pp.53-68). Kaposvár, Hungary.

16. Kumar, Y., Yadav, D.N., Ahmad, T., Narsaiah, K. 2015. Recent trends in the use of natural antioxidants for meat and meat products. Comprehensive Reviews in Food Science and Food Safety. 14(6): 796-812.

17. Lopez-Ferrer, S., Baucells, M.D., Barroeta, A.C., Grashorn, M.A. 2001. n-3 Enrichment of chicken meat. 1. Use of very long-chain fatty acids in chicken diets and their influence on meat quality. Fish oil. Poultry Science. 80(6): 741-752.

18. Meilgaard, M.C., Civille, G.C., Carr, B.T. 1987. Sensory Evaluation Techniques. Volume II. CRC Press, Boca Raton, FL, USA. pp. 176.

19. Nieto, G., Díaz, P., Bañón, S., Garrido, M. D. 2010. Dietary administration of ewe diets with a distillate from rosemary leaves (Rosmarinus officinalis L.): Influence on lamb meat quality. Meat Science. 84(1): 23-29.

20. SAS Institute Inc. 1990. SAS ${ }^{\circledR}$ Procedures Guide, Version 6, Third Edition, Cary, NC: SAS Institute Inc.

21. Shikov, V., Kammerer, D. R., Mihalev, K., Mollov, P., Carle, R. 2012. Heat stability of strawberry anthocyanins in model solutions containing natural copigments extracted from rose (Rosa damascena Mill.) petals. Journal of Agricultural and Food Chemistry. 56(18): 8521-8526. 
22. Sobolev, A., Gutyj, B., Grynevych, N., Bilkevych V., Mashkin, Y. 2017.

Enrichment of meat products with selenium by its introduction to mixed feed compounds for birds. Regulatory Mechanisms in Biosystems. 8(3): 417-422.

23. Terpstra, A.H.M., Beynen, A.C., Everts, H., Kocsis, S., Katan, M.B., Zock, P.L. 2002. The decrease in body fat inmice fed conjugated linoleic acid is due to increases in energy expenditure and energy loss in the excreta. Journal of Nutrition. 132(5): 940-945.

24. Toldrá, F., Reig, M. 2011. Innovations for healthier processed meats. Trends in Food Science \& Technology. 22(9): 517-522.

25. Ventanas, S., Ventanas, J., Tovar, J., García, C., Estévez, M. 2007. Extensive feeding versus oleic acid and tocopherol enriched mixed diets for the production of Iberian dry-cured hams: Effect on chemical composition, oxidative status and sensory traits. Meat Science. 77(2): 246-256.

26. Vlahova-Vangelova, D., Balev, D., Dragoev, S., Kapitanski, B., Mihalev, K., Doncheva, T. 2014. Influence of goji berry, pumpkin powder and rose petal extract on the quality of cooked sausages with reduced nitrite content. In: Proceedings of the $2^{\text {nd }}$ International Congress, "Food Technology, Quality and Safety" (pp.1-6). Novi Sad, Serbia.

27. Wiklund, E., Pickova, J., Sampels, S., Lundström, K. 2001. Fatty acid composition of m. longissimus lumborum, ultimate muscle $\mathrm{pH}$ values and carcass parameters in reindeer (Rangifer tarandus tarandus L) grazed on natural pasture or fed a commercial feed mixture. Meat Science. 58(3): 293-298.

28. Young, O. A., West, J., Hart, A.L., van Otterdijk, F.F.H. 2004. A method for early determination of meat ultimate pH. Meat Science. 66(2): 493-498. 